\title{
Geochemical characteristics of Mesoproterozoic metabasite dykes from the Chhotanagpur Gneissic Terrain, eastern India: Implications for their emplacement in a plate margin tectonic environment
}

\author{
Rajesh K Srivastava ${ }^{1, *}$, Anup K Sinha ${ }^{1,2}$ and Suresh Kumar ${ }^{1,3}$ \\ ${ }^{1}$ Centre of Advanced Study, Department of Geology, Banaras Hindu University, Varanasi 221 005, India. \\ ${ }^{2}$ Present address: Dr. K. S. Krishnan Geomagnetic Research Laboratory, Jhusi, Allahabad 211505 , India. \\ ${ }^{3}$ Present address: Geological Survey of India, Jabalpur 482 003, India. \\ *Corresponding author.e-mail: rajeshgeolbhu@yahoo.com
}

\begin{abstract}
A number of mafic intrusive bodies (mostly dykes) are exposed in the Chhotanagpur Gneissic Terrain (CGT). Most dykes trend in ENE-WSW to E-W following major structural trends of the region. These metabasite dykes show granoblastic to grano-nematoblastic textures and contain hornblende, plagioclase, chlorite, quartz and epidote which suggest their metamorphism under amphibolite grade $\mathrm{P}-\mathrm{T}$ conditions. Although no radiometric age is available for the metabasite dykes, field relationships with host rock and available geochronology on granitoids suggest their emplacement during Mesoproterozoic. Geochemical characteristics of these dykes classify them as low-K tholeiite to medium-K calcalkaline type. At least two types of metabasite dykes are recognized on the basis of their HFSE contents; one group shows entirely calc-alkaline nature, whereas the other group has rocks of tholeiite-calc-alkaline series. High Mg\# observed in a number of samples indicates their derivation from primary melt. Multielement spidergrams and rare-earth element patterns observed in these samples also corroborate their derivation from different magma batches. Trace element patterns observed for $\mathrm{Nb}-\mathrm{Ta}, \mathrm{Hf}-\mathrm{Zr}, \mathrm{Sr}$ and $\mathrm{Y}$ suggesting involvement of subduction related processes in the genesis of CGT metabasite dykes. Perceived geochemical characteristics suggest that metamorphism did not affect much on the chemistry of metabasites but source region, responsible for the generation of CGT metabasites, was possibly modified during subduction process. This study suggests that magma generated in a destructive plate setting fed the Mesoproterozoic mafic dykes of the CGT.
\end{abstract}

\section{Introduction}

Dykes signify crustal extension and are important indicators of crustal stabilization events, supercontinental assembly and dispersal. Crust-mantle interaction plays a significant role in the delineation of crustal provinces as well as in deciphering crustal evolution events (Halls 1982; Bleeker and Ernst
2006; Ernst et al 2010; Srivastava 2011 and references therein). Mafic dyke swarms are prominent landmarks in Archaean granite-greenstone and gneiss-granulite terrains, Proterozoic sedimentary basins, Phanerozoic rift valleys and Large Igneous Provinces (LIPs). Many researchers have pointed out that dykes are an integral part of continental rifting and supposed to be valuable time

Keywords. Mesoproterozoic; metabasite dykes; geochemistry; plate margin setting; Chhotanagpur gneissic terrain; eastern India. 
markers and may be used as global correlation tools (Bleeker and Ernst 2006; Halls 2008; Ernst et al 2010; Srivastava 2011). These are valuable tools to unravel successive tectonic events in Precambrian basement complexes. Petrogenetic modelling is being increasingly applied to find a suitable mantle connection for the giant dyke swarms.

The Indian shield was an important member during the making and breaking of Precambrian supercontinents like Columbia and Rodinia and remains an important natural laboratory where several petrotectonic models can be tested (Rogers 1996; Meert 2002; Rogers and Santosh 2002, 2009; Pisarevsky et al 2003; Zhao et al 2004; Hou et al 2008; Yakubchuk 2010 and references therein). The Indian shield is one of the oldest continental blocks of the world and comprises various cratons, mobile belts, shear zones, rift valleys and platformal sedimentary basins (figure 1a; Naqvi and Rogers 1987; Mahadevan 2009; Ramakrishnan and Vaidyanadhan 2010) and all these blocks have been traversed by different generations of dykes (Murthy 1987; Devaraju 1995; Srivastava et al 2008a, 2008b; Srivastava 2011 and references therein). A number of mafic dykes (and sills) are reported to intrude the Chhotanagpur Gneissic Terrain (CGT) but very limited petrological and geochemical details are available (Ghose et al 2005; Kumar and Ahmad 2007; Ghose and Chatterjee 2008). Ages of these mafic intrusives range from Mesoproterozoic to late Cretaceous (Sarkar 1968; Baksi 1995; Kent et al 2002; Ghose et al 2005; Ghose and Chatterjee 2008). Ghose et al (2005) have studied metabasite rocks exposed south of the Damodar valley and suggested their emplacement in an intracratonic setting. Ghose and Chatterjee (2008) stated that five major intra-continental rift/shear zones controlled the magmatism in the CGT. Four of them trend in ENE-WSW to E-W direction and most of the studied metabasite dykes follow these major tectonic features. Kumar and Ahmad (2007) studied amphibolite dykes from the CGT, exposed north of the Damodar valley, for their petrological and geochemical characteristics and suggested their emplacement in an extensional tectonic regime and genesis through partial melting of an enriched mantle sources. In this paper, we present further petrological and geochemical data on poorly-studied metabasite dykes exposed around Jharia and Raniganj Gondwana basins (figure 1b), particularly north of the Damodar valley, from the CGT, eastern India to evaluate their possible emplacement tectonic environment during the Mesoproterozoic.

\section{Geological setting}

The eastern part of the Indian shield consists mainly of Singhbhum craton (inclusive of CGT) and Shillong plateau. The Singhbhum craton is surrounded by Mahanadi rift (and Sukinda thrust) in SW, Narmada-Son rift, Gangetic alluvium and Mahakoshal-Satpura belt in NW, Eastern Ghats belt (and Indo-Gangetic Bengal basin) in SE and Rajmahal traps in E-NE (figure 1b). CGT experienced polyphase deformation, metamorphism and magmatism, which comprises mainly granite gneisses, migmatites, porphyritic granite and metasedimentary enclaves (Ghose 1983;

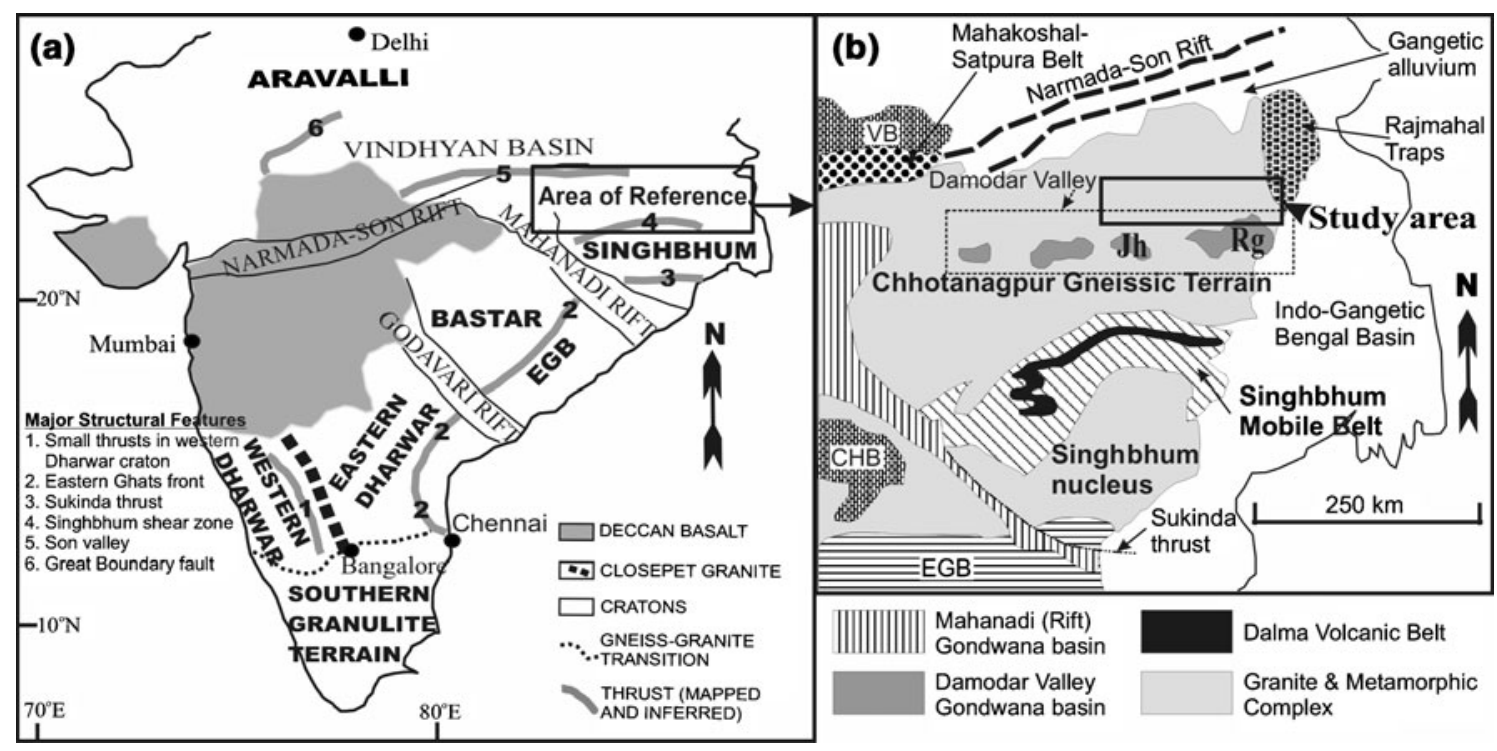

Figure 1. (a) Major cratons and structural features of India (after Naqvi and Rogers 1987). (b) Generalized geological map of the Chhotanagpur Gneissic Terrain and distribution of Gondwana basins in the Damodar Valley, Eastern India (modified after Acharyya 2003). VB: Vindhyan basin; CHB: Chhattisharh basin; EGB: Eastern Ghats Belt; Jh: Jharia; Rg: Raniganj. 
Mahadevan 2002). There is no consensus on the nature of CGT and its relation with the Singhbhum craton. There is a debate over the nature of CGT; whether it is a mobile belt or a cratonic block. Many researchers interpreted CGT as a separate identity and its nature as a mobile belt (Ghose 1983; Mukhopadhyay 1988; Mahadevan 2002; Ghose and Chatterjee 2008 and references therein) but others argue for a cratonic nature of CGT (Naqvi and Rogers 1987; Kumar and Ahmad 2007; Sharma 2009; Srivastava et al 2009). Naqvi and Rogers (1987) divided Singhbhum craton into Singhbhum Nucleus and Chhotanagpur belt, separated by Singhbhum mobile belt. Recently, Sharma (2009) considers CGT to be a cratonic region of Archaean antiquity whose convergence with the Singhbhum craton in the south gave rise to the Singhbhum mobile belt. He further states that medium-grade enclaves of metasediments and basic rocks do not support its mobile belt nature. Occurrences of komatiite (Bhattacharya et al 2010) and potassic intrusives (Srivastava et al 2009) also support cratonic nature of CGT. Srivastava et al (2009) suggested that potassic intrusive, which show characteristic of orangeites, lamproites or aillikites, support their emplacement in an extensional tectonic regime. A thinned lithosphere and the inheritance of an ancient subducted component played a significant role in the petrogenesis of these potassic intrusives. Present authors are also of the opinion that CGT should be considered as a cratonic block but, certainly, we need comprehensive study of basement rocks with their precise radiometric ages.

Proterozoic mafic intrusions (mostly dykes) are widely encountered from the CGT, frequently intruded within the basement gneisses but not to the massif anorthosite and granite plutons (Ghose 1983; Mahadevan 2002; Ghose et al 2005; Kumar and Ahmad 2007; Ghose and Chatterjee 2008). They are metamorphosed and at places co-folded with the gneisses and metasediments (Ghose et al 2005; Kumar and Ahmad 2007; Ghose and Chatterjee 2008). They trend in ENE-WSW to E-W following major structural trends, which probably existed since Archaean (Ghose and Chatterjee 2008; Bhattacharya et al 2010). Very scanty geochronological data is available for the metabasite dykes. Sarkar (1968) dated amphibolite (basic magmatism) samples from Simultala by $\mathrm{K}-\mathrm{Ar}$ method and placed it at 1416-1246 Ma but probably it provides metamorphic age of these samples rather than magmatic age. Chatterjee et al (2008) presented $\mathrm{U}-\mathrm{Pb}$ zircon age for Bengal anorthosite massif, which also has associated gabbro, and placed it at $1550 \pm 12$ Ma. The Bihar Mica Belt (BMB), the Munger Group and the Rajgir-Gaya sub-basins, showing basement-cover relationship with the CGT gneisses, represent the northern margin of the CGT (Ghose and Mukherjee
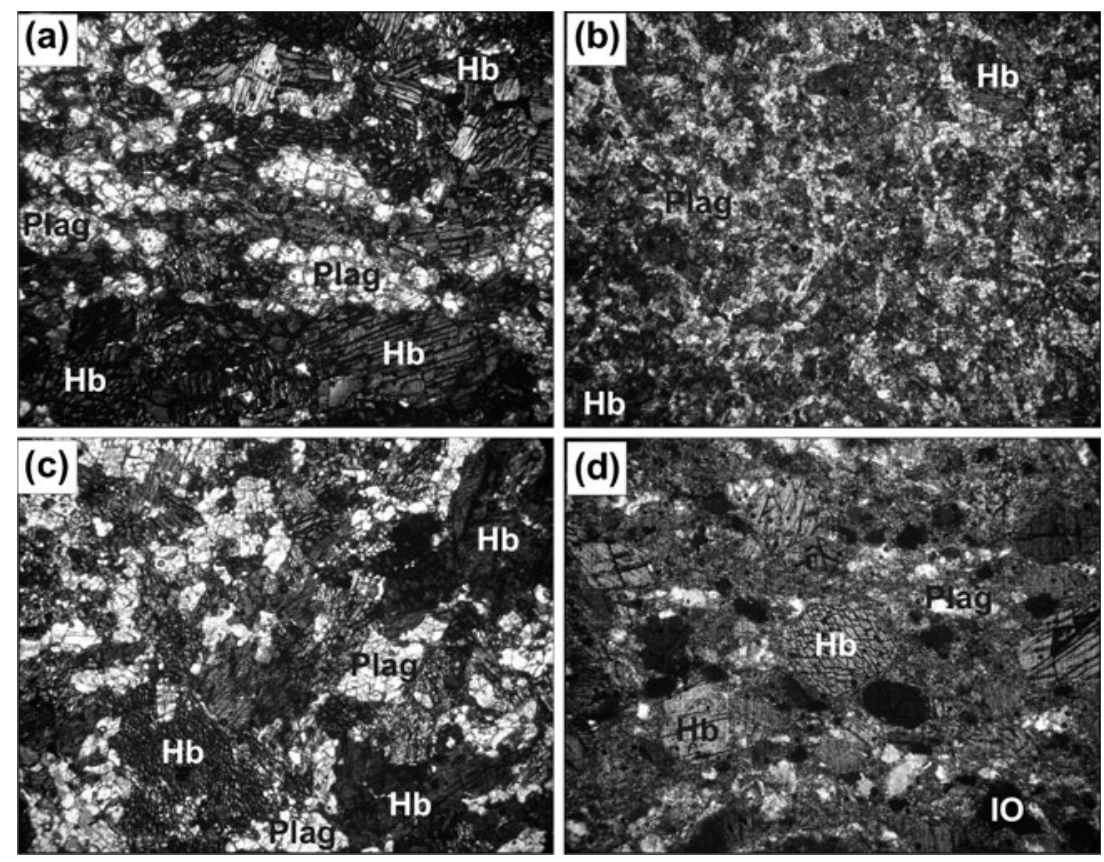

Figure 2. Photomicrographs of the studied metabasite dykes. (a) Metabasite showing linear arrangement of hornblende $(\mathrm{Hb})$ and plagioclase feldspar (Plab) exhibiting grano-nematoblastic texture. (b) A medium-grained metabasite dyke. Although metamorphosed, somewhat igneous texture is still preserved. (c) Metabasite with granoblatic texture. A number of hornblende ( $\mathrm{Hb}$ ) grains show two sets of oblique cleavages. (d) Metabasite in crossed-polars. Few grains of iron-oxides (IO) are seen in this photograph. Except $(\mathrm{d})$, all other photographs are taken under polarized light. Width of each photograph is equivalent to $3.5 \mathrm{~mm}$. 
2000). Pandey et al (1986) dated intrusive granite from the BMB by $\mathrm{Rb}-\mathrm{Sr}$ method which yielded a $1590 \pm 30 \mathrm{Ma}$ date, whereas gneiss from the south of the mica belt has been dated at $1717 \pm$ 102 Ma (Mallik et al 1991). Recently, Chatterjee and Ghose (2011) have identified early Proterozoic intrusive granite in the Gaya-Rajgir belt which is older than those reported $(<1600 \mathrm{Ma})$ either in the CGT or BMB. They obtained chemical date for monazite-xenotime from the intrusive porphyritic granite and suggested that monazite crystallized at $1697 \pm 17 \mathrm{Ma}$ in porphyritic granite that lacks $1.6 \mathrm{Ga}$ thermal imprints. From the field-setting as well as available geochronological ages from different granitoids, it is observed that occurrences of metabasic rocks may have preceded anorthosite and porphyritic granite magmatisms. This eventually reflects Mesoproterozoic age for the studied metabasic intrusives (dykes).

\section{Petrography}

Petrography of metabasite dykes exposed in the CGT is described in detail by previous researchers (e.g., Ghose et al 2005; Kumar and Ahmad 2007; Ghose and Chatterjee 2008). A brief petrography of samples studied for the present work is presented here. They are medium- to coarse-grained and hardly any igneous minerals and textures are seen. Grano-nematoblastic texture (defined by linear arrangement of hornblende and plagioclase grains (figure 2a, b)) and granoblastic texture (defined by equi-granular hornblende and plagioclase grains (figure 2c, d)) are observed in most thin sections. Most of the studied rocks consist of hornblende, plagioclase, chlorite, quartz, epidote, apatite, titanite, and iron oxides. The observed textures and mineral compositions of the studied samples indicate their metamorphism under amphibolites grade $\mathrm{P}-\mathrm{T}$ conditions.

\section{Analytical techniques}

As metabasite dykes of the study area have undergone hydrothermal alteration and amphibolite grade metamorphism, there is a possibility of variable element mobility during these post-magmatic processes. During the field-trips we ensured that

Table 1. Whole rock major oxides (wt\%), CIPW norms, trace and rare-earth element compositions of metabasite dykes from the Chhotanagpur Gneissic Terrain, eastern India.

\begin{tabular}{|c|c|c|c|c|c|c|c|c|c|c|}
\hline $\begin{array}{l}\text { Sample } \\
\text { no. }\end{array}$ & $\begin{array}{c}\text { CGT05/ } \\
\text { JH16 }\end{array}$ & $\begin{array}{c}\text { CGT06/ } \\
\text { JH32 }\end{array}$ & $\begin{array}{c}\text { CGT06/ } \\
\text { JH33 }\end{array}$ & $\begin{array}{c}\text { CGT06/ } \\
\text { JH40 }\end{array}$ & $\begin{array}{c}\text { CGT06/ } \\
\text { JH50 }\end{array}$ & $\begin{array}{c}\text { CGT06/ } \\
\text { JH52 }\end{array}$ & $\begin{array}{c}\text { CGT06/ } \\
\text { JH53 }\end{array}$ & $\begin{array}{c}\text { CGT08/ } \\
\text { JH1 }\end{array}$ & $\begin{array}{c}\text { CGT08/ } \\
\text { TC-5 }\end{array}$ & $\begin{array}{c}\text { CGT08/ } \\
\text { BK-4 }\end{array}$ \\
\hline \multicolumn{11}{|c|}{ Major oxides (wt\%) } \\
\hline $\mathrm{SiO}_{2}$ & 47.10 & 52.17 & 57.19 & 54.01 & 47.76 & 47.52 & 43.30 & 48.86 & 50.68 & 49.15 \\
\hline $\mathrm{TiO}_{2}$ & 0.92 & 1.24 & 0.95 & 0.83 & 0.44 & 0.47 & 0.30 & 1.09 & 0.53 & 0.37 \\
\hline $\mathrm{Al}_{2} \mathrm{O}_{3}$ & 16.98 & 15.48 & 15.96 & 11.59 & 16.27 & 15.66 & 19.08 & 15.83 & 16.07 & 22.39 \\
\hline $\mathrm{Fe}_{2} \mathrm{O}_{3}$ & 11.07 & 11.81 & 9.43 & 8.97 & 9.00 & 9.19 & 11.73 & 12.63 & 9.85 & 6.26 \\
\hline $\mathrm{MnO}$ & 0.17 & 0.15 & 0.14 & 0.17 & 0.16 & 0.14 & 0.15 & 0.19 & 0.18 & 0.10 \\
\hline $\mathrm{MgO}$ & 7.24 & 5.29 & 3.72 & 9.91 & 9.87 & 9.47 & 12.39 & 7.07 & 6.48 & 4.72 \\
\hline $\mathrm{CaO}$ & 11.43 & 8.67 & 6.05 & 9.92 & 14.51 & 14.61 & 10.68 & 11.02 & 10.96 & 13.32 \\
\hline $\mathrm{Na}_{2} \mathrm{O}$ & 2.30 & 2.48 & 2.93 & 1.60 & 1.47 & 1.64 & 1.32 & 2.40 & 2.77 & 2.73 \\
\hline $\mathrm{K}_{2} \mathrm{O}$ & 0.76 & 1.28 & 1.91 & 1.99 & 0.21 & 0.24 & 0.19 & 0.52 & 0.40 & 0.25 \\
\hline $\mathrm{P}_{2} \mathrm{O}_{5}$ & 0.32 & 0.22 & 0.24 & 0.25 & 0.10 & 0.09 & 0.08 & 0.25 & 0.09 & 0.05 \\
\hline LOI & 1.09 & 1.22 & 1.20 & 1.08 & 0.57 & 0.80 & 1.07 & 0.77 & 0.49 & 0.49 \\
\hline Total & 99.38 & 100.01 & 99.72 & 100.32 & 100.36 & 99.83 & 100.29 & 100.63 & 98.50 & 99.83 \\
\hline $\mathrm{Mg} \#$ & 60.46 & 52.98 & 50.68 & 73.54 & 71.94 & 70.66 & 70.37 & 56.68 & 62.33 & 63.80 \\
\hline \multicolumn{11}{|c|}{ CIPW norm compositions } \\
\hline Q & - & 4.94 & 12.12 & 3.97 & - & - & - & - & 0.44 & - \\
\hline Or & 4.62 & 7.73 & 11.54 & 11.94 & 1.25 & 1.44 & 1.15 & 3.11 & 2.43 & 1.50 \\
\hline $\mathrm{Ab}$ & 20.00 & 21.44 & 25.35 & 13.74 & 12.56 & 14.12 & 11.37 & 20.55 & 24.11 & 23.38 \\
\hline An & 34.68 & 27.93 & 25.31 & 18.84 & 37.54 & 35.28 & 46.42 & 31.27 & 31.09 & 48.68 \\
\hline Di & 17.53 & 11.99 & 3.12 & 23.65 & 27.84 & 30.64 & 5.68 & 18.44 & 19.77 & 14.57 \\
\hline Hy & 4.34 & 19.33 & 16.80 & 22.87 & 5.15 & 1.56 & 0.62 & 14.39 & 17.79 & 2.16 \\
\hline $\mathrm{Ol}$ & 13.77 & - & - & - & 12.56 & 13.77 & 31.94 & 6.74 & - & 7.48 \\
\hline $\mathrm{Mt}$ & 2.51 & 3.72 & 3.35 & 2.81 & 2.01 & 2.07 & 2.06 & 2.83 & 3.12 & 1.40 \\
\hline Il & 1.80 & 2.41 & 1.84 & 1.60 & 0.84 & 0.91 & 0.58 & 2.10 & 1.03 & 0.71 \\
\hline Ap & 0.76 & 0.52 & 0.57 & 0.59 & 0.23 & 0.21 & 0.19 & 0.59 & 0.21 & 0.19 \\
\hline
\end{tabular}


Table 1. (Continued).

\begin{tabular}{|c|c|c|c|c|c|c|c|c|c|c|}
\hline $\begin{array}{l}\text { Sample } \\
\text { no. }\end{array}$ & $\begin{array}{c}\text { CGT05/ } \\
\text { JH16 }\end{array}$ & $\begin{array}{c}\text { CGT06/ } \\
\text { JH32 }\end{array}$ & $\begin{array}{c}\text { CGT06/ } \\
\text { JH33 }\end{array}$ & $\begin{array}{c}\text { CGT06/ } \\
\text { JH40 }\end{array}$ & $\begin{array}{c}\text { CGT06/ } \\
\text { JH50 }\end{array}$ & $\begin{array}{c}\text { CGT06/ } \\
\text { JH52 }\end{array}$ & $\begin{array}{c}\text { CGT06/ } \\
\text { JH53 }\end{array}$ & $\begin{array}{c}\text { CGT08/ } \\
\text { JH1 }\end{array}$ & $\begin{array}{c}\text { CGT08/ } \\
\text { TC-5 }\end{array}$ & $\begin{array}{c}\text { CGT08/ } \\
\text { BK-4 }\end{array}$ \\
\hline TAS class $^{\mathrm{a}}$ & $\mathrm{SAB}$ & $\mathrm{BA}$ & $\mathrm{A}$ & $\mathrm{BA}$ & $\mathrm{SAB}$ & $\mathrm{SAB}$ & PIC & $\mathrm{SAB}$ & $\mathrm{BA}$ & $\mathrm{SAB}$ \\
\hline \multicolumn{11}{|c|}{ Trace elements (ppm) } \\
\hline $\mathrm{Cr}$ & $*$ & 120 & 120 & 530 & 810 & 160 & 120 & 210 & 190 & 180 \\
\hline $\mathrm{Ni}$ & $*$ & 100 & 40 & 140 & 110 & 90 & 230 & 60 & 30 & 60 \\
\hline $\mathrm{Rb}$ & $*$ & 40 & 61 & 88 & 5 & 2 & 6 & 20 & 11 & 2 \\
\hline $\mathrm{Ba}$ & 248 & 489 & 712 & 714 & 98 & 83 & 103 & 184 & 125 & 90 \\
\hline $\mathrm{Sr}$ & 473 & 433 & 338 & 320 & 371 & 459 & 551 & 366 & 201 & 241 \\
\hline $\mathrm{Nb}$ & $*$ & 7 & 7 & 9 & 1 & 1 & 1 & 2 & 1 & 1 \\
\hline $\mathrm{Ta}$ & $*$ & 0.30 & 0.40 & 0.50 & - & - & - & 0.20 & - & - \\
\hline $\mathrm{Zr}$ & 56 & 129 & 136 & 196 & 12 & 13 & 9 & 55 & 24 & 26 \\
\hline $\mathrm{Hf}$ & $*$ & 3.40 & 3.80 & 5.70 & 0.50 & 0.60 & 0.30 & 1.50 & 0.70 & 0.80 \\
\hline $\mathrm{Y}$ & 18 & 34 & 31 & 23 & 9 & 9 & 4 & 20 & 13 & 8 \\
\hline $\mathrm{V}$ & 256 & 285 & 167 & 182 & 171 & 227 & 111 & 279 & 176 & 115 \\
\hline $\mathrm{Ga}$ & $*$ & 21 & 21 & 15 & 13 & 15 & 14 & 17 & 12 & 14 \\
\hline $\mathrm{Th}$ & $*$ & 3.10 & 6.90 & 10.10 & 0.20 & 0.50 & 0.30 & 0.70 & 0.50 & 0.40 \\
\hline $\mathrm{U}$ & $*$ & 1.00 & 1.70 & 2.90 & - & 0.20 & 0.30 & 0.20 & 0.10 & - \\
\hline \multicolumn{11}{|c|}{ Rare-earth elements (ppm) } \\
\hline $\mathrm{La}$ & $*$ & 21.30 & 28.10 & 27.50 & 4.00 & 4.10 & 3.40 & 9.40 & 4.20 & 3.50 \\
\hline $\mathrm{Ce}$ & $*$ & 50.50 & 61.10 & 66.40 & 9.90 & 10.40 & 8.00 & 22.20 & 8.00 & 6.80 \\
\hline $\operatorname{Pr}$ & $*$ & 6.16 & 7.07 & 7.79 & 1.37 & 1.40 & 1.03 & 2.73 & 1.20 & 0.99 \\
\hline $\mathrm{Nd}$ & $*$ & 26.40 & 28.50 & 30.70 & 6.60 & 6.80 & 4.60 & 12.60 & 5.10 & 4.20 \\
\hline $\mathrm{Sm}$ & $*$ & 5.80 & 6.10 & 5.70 & 1.70 & 1.70 & 1.00 & 3.50 & 1.60 & 1.20 \\
\hline $\mathrm{Eu}$ & $*$ & 1.63 & 1.81 & 1.51 & 0.76 & 0.74 & 0.51 & 1.30 & 0.77 & 0.50 \\
\hline $\mathrm{Gd}$ & $*$ & 6.00 & 6.10 & 4.90 & 1.80 & 2.00 & 1.10 & 3.80 & 1.90 & 1.50 \\
\hline $\mathrm{Tb}$ & $*$ & 1.10 & 1.00 & 0.70 & 0.30 & 0.30 & 0.20 & 0.60 & 0.40 & 0.30 \\
\hline Dy & $*$ & 6.10 & 6.10 & 4.30 & 1.80 & 1.80 & 0.90 & 3.70 & 2.30 & 1.60 \\
\hline Ho & $*$ & 1.30 & 1.20 & 0.80 & 0.30 & 0.30 & 0.20 & 0.80 & 0.50 & 0.30 \\
\hline Er & $*$ & 3.70 & 3.60 & 2.40 & 1.00 & 1.00 & 0.50 & 2.30 & 1.60 & 1.10 \\
\hline $\mathrm{Tm}$ & $*$ & 0.55 & 0.53 & 0.36 & 0.14 & 0.14 & 0.07 & 0.34 & 0.29 & 0.18 \\
\hline $\mathrm{Yb}$ & $*$ & 3.50 & 3.50 & 2.30 & 0.90 & 0.90 & 0.50 & 2.10 & 1.60 & 1.00 \\
\hline $\mathrm{Lu}$ & $*$ & 0.51 & 0.53 & 0.36 & 0.13 & 0.13 & 0.07 & 0.32 & 0.23 & 0.14 \\
\hline
\end{tabular}

${ }^{a}$ Classification by SINCLAS computer program (cf. Verma et al 2002): SAB: sub-alkaline basalt; BA: basaltic andesite; A: andesite; PIC: picrite.

-: below detection limits; $*$ : not analyzed.

samples should be collected from middle of the dykes and devoid of any vein or alteration to minimize the effects of secondary processes. Samples were re-checked for any vein or alteration while preparing powder for the chemical analyses. Out of the 35 samples collected from the metabasite dykes, 10 were selected for whole rock major oxides, trace and rare-earth element analyses. All analyses were done at the Activation Laboratories Ltd., Ancaster, Ontario, Canada. ICP-OES (Model: Thermo-JarretAsh ENVIRO II) was used to analyse major elements, whereas ICPMS (Model: Perkin Elmer Sciex ELAN 6000) was used to determine trace element concentrations. The precision is approximately 5 and $5-10 \%$ for the major oxides and trace elements, respectively, when reported at $100 \times$ detection limit. Several standards, such as MRG1, W2, DNC1, STM1 and
SY3, were run to check accuracy and precision. All the chemical data are presented in table 1 . The SINCLAS computer program was used to calculate CIPW Normative compositions, $\mathrm{Mg} \#$ and TAS classification (Verma et al 2002).

\section{Geochemistry}

A wide range of variations in major oxides is observed from the studied metabasite dyke samples. $\mathrm{SiO}_{2}$ (wt\%) varies from 43.30 to 57.19, whereas $\mathrm{MgO}$ (wt\%) varies between 3.72 (most differentiated and andesitic in nature) and 12.39 (primitive and picritic in nature). $\mathrm{Fe}_{2} \mathrm{O}_{3}$ (wt\%) varies from 6.26 to 12.63 and $\mathrm{CaO}$ (wt\%) from 6.05 to 14.61 . Most samples show lower concentration of $\mathrm{TiO}_{2}$ (0.30 to $\left.1.24 \mathrm{wt} \%\right)$. This wide range 
of major oxides is well reflected in their CIPW normative compositions; varies from quartz normative (max. $12.12 \%$ ) to olivine normative (max. $31.94 \%$ ) (see table 1$)$. $\mathrm{Mg}$ number $(\mathrm{Mg} \#)$ is moderately high in these samples and varies between 50.68 and 73.54. The SINCLAS computer program classifies these metabasites into sub-alkaline basalts (five samples), basaltic andesites (three samples), picrite (Sample no. CGT06/JH53) and andesite (Sample no. CGT06/JH33). This is also revealed from the total-alkali silica diagram (TAS; figure 3a; Le Maitre 2002) but all samples show sub-alkaline tholeiitic nature (figure 3a; Irvine and Baragar 1971). These samples are also plotted on classificatory diagram based on incompatible elements ( $\mathrm{Zr}, \mathrm{Ti}, \mathrm{Nb}$ and $\mathrm{Y}$; Winchester and
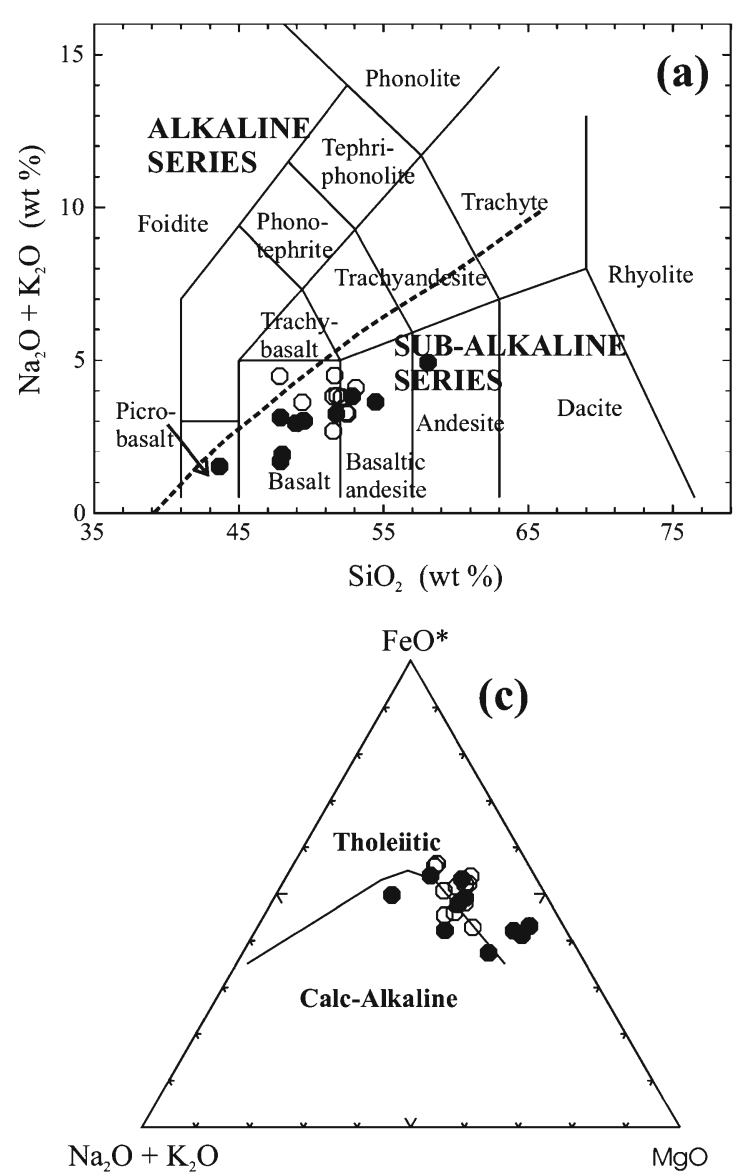
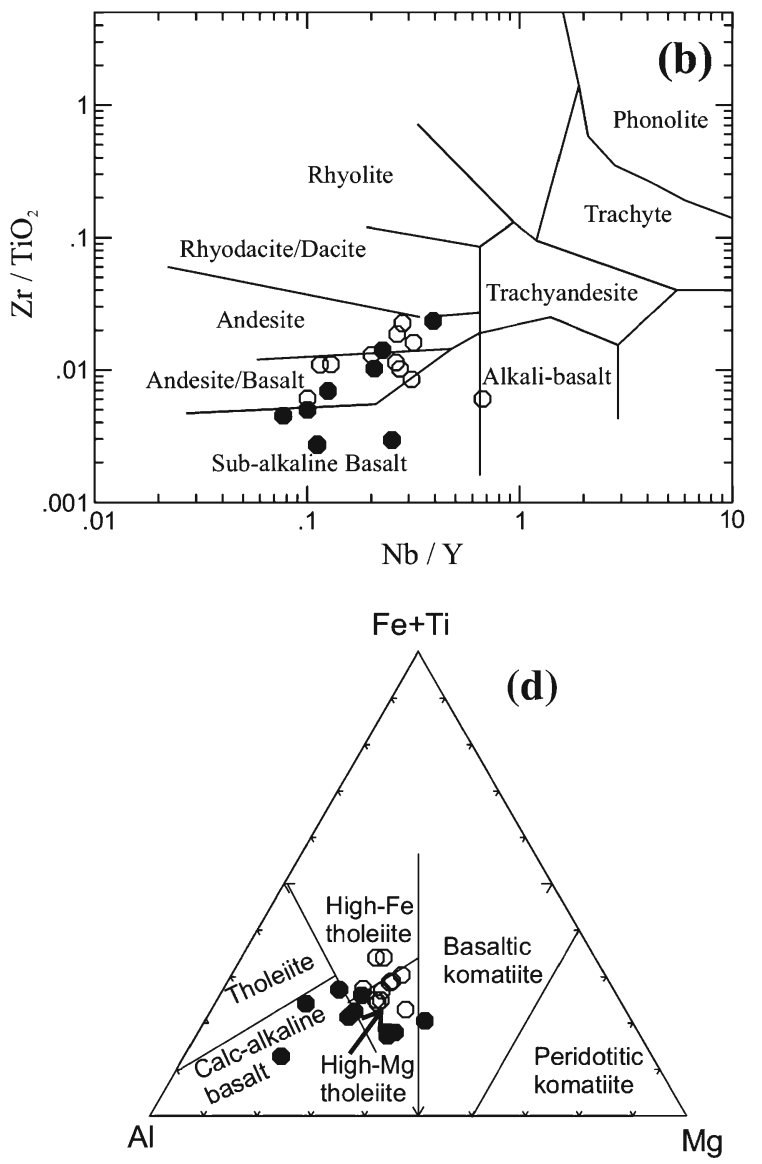

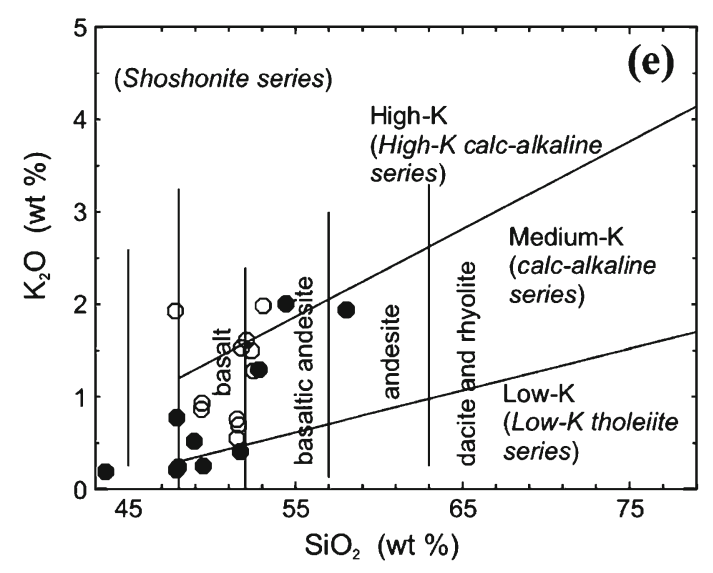

Figure 3. (a) Total-alkali silica (TAS) classification diagram (after Le Maitre 2002); dotted line discriminates between subalkaline basalts and alkaline basalts (after Irvine and Baragar 1971). (b) Nb/Y versus $\mathrm{Zr} / \mathrm{TiO}_{2}$ diagram (after Winchester and Floyd 1977). (c) AFM triangular diagram (after Irvine and Baragar 1971). (d) Jensen's cation plot (Jensen 1976). (e) $\mathrm{SiO}_{2}-\mathrm{K}_{2} \mathrm{O}$ diagram. This diagram shows the subdivisions of Le Maitre (2002) and Rickwood (1989; mentioned in italics). ๑: present studied metabasite samples; $\bigcirc$ : metabasite samples studied by Kumar and Ahmad (2007). 
Floyd 1977; figure 3b) which depict similar nature. From these plots and their CIPW norm compositions, they may be classified as sub-alkaline quartz tholeiites (andesitic) to olivine tholeiites (picritic). Some other classificatory diagrams which discriminate tholeiites from calc-alkaline series are also used. On AFM plot (figure 3c; Irvine and Baragar 1971) most of the studied samples show their tholeiitic characteristics but few samples showed calc-alkaline nature. Similar picture is observed on Jensen's cation plot (figure 3d; Jensen 1976). Jensen's plot is useful to classify metamorphosed igneous rocks which have suffered mild metasomatic loss of alkalis, as observed in present case. Metabasite samples studied by Kumar and Ahmad (2007) are also plotted on all these classificatory diagrams for comparison and found very close similarities with the present studied samples. These observations suggest that metabasite dyke samples from the CGT region may be classified as sub-alkaline tholeiites with some affinity to calc-alkaline nature. It is significant to note that many studied samples show high $\mathrm{Mg} \#(>70)$ and some (CGT06/JH40 and CGT06/JH50) also show high Ni-Cr contents, which suggests their primary nature. Calc-alkaline nature of few samples is also corroborated in the $\mathrm{SiO}_{2}-\mathrm{K}_{2} \mathrm{O}$ plot (figure 3e; after Rickwood 1989; Le Maitre 2002).

To observe crystallization behaviour of studied metabasite dyke samples few Harker-type variation diagrams are examined. Figure 4 presents variations of major oxides with reference to $\mathrm{MgO}$ content. It is not easy to establish any specific trend in these plots but $\mathrm{SiO}_{2}$, and alkalis show sketchy differentiation trends; these oxides increase with decreasing $\mathrm{MgO} . \mathrm{Fe}_{2} \mathrm{O}_{3}$ and $\mathrm{Al}_{2} \mathrm{O}_{3}$ do not show any trend. This is explicable because these elements are supposed to be mobile during the post-magmatic processes such as metamorphism, hydrothermal alteration and deformation (Rollinson 1993; Jochum and Verma 1996 and references therein). But it is difficult to understand
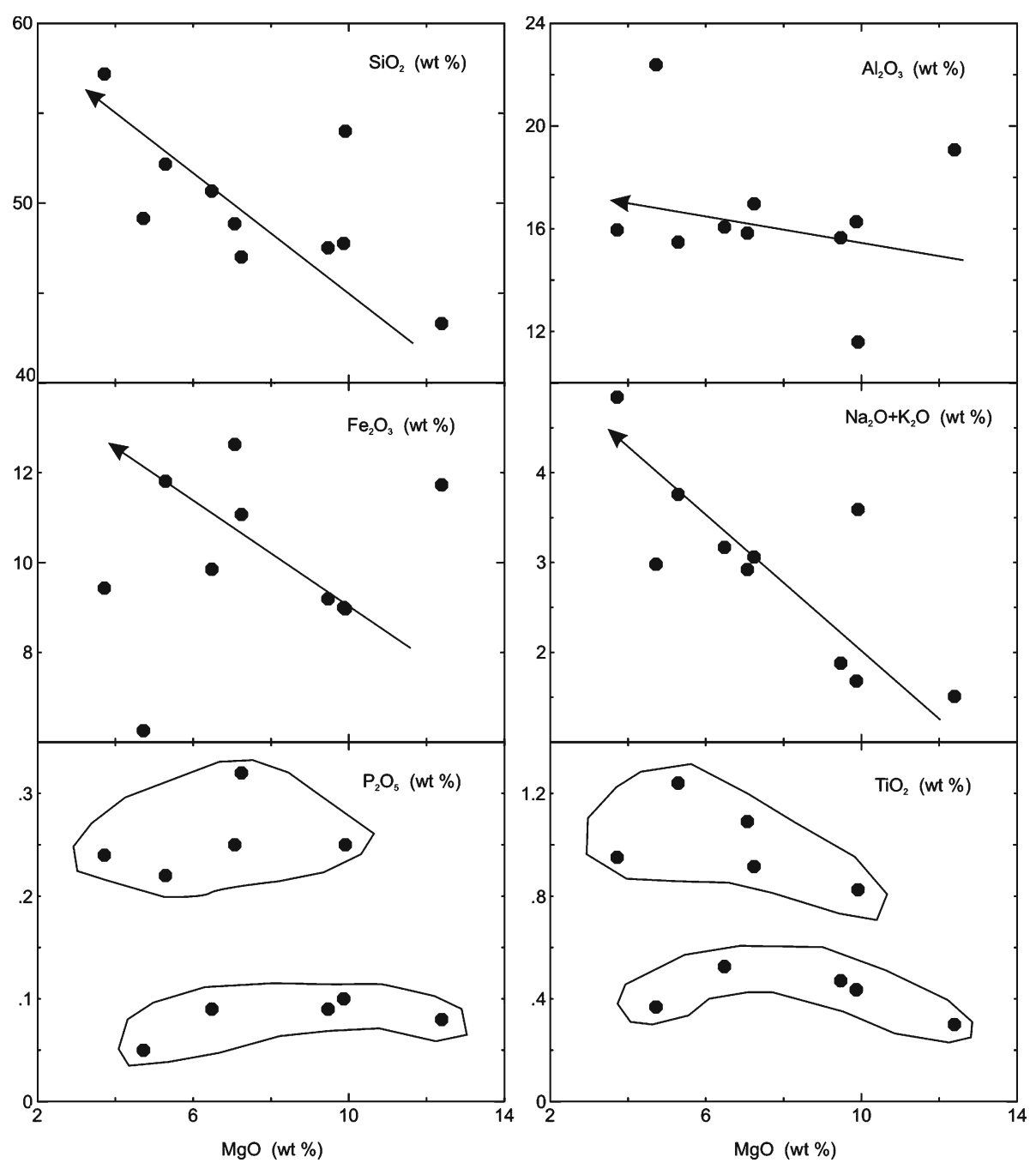

Figure 4. Harker-type variation diagram for major oxides. 
why $\mathrm{TiO}_{2}$ and $\mathrm{P}_{2} \mathrm{O}_{5}$ do not show any specific trend as these elements are supposed to be immobile during the post-magmatic processes (Rollinson 1993; Jochum and Verma 1996 and references therein). This may be due to either these samples are not co-genetic or they might be derived from different magma batches as samples plot in two groups.

$\mathrm{Cr}$ and $\mathrm{Ni}$ and some selected large-ion lithophile elements (LILEs) are plotted to observe their variations against $\mathrm{MgO}$ contents to demonstrate crystallization behaviours (figure 5). Except few samples, most of the plots show some linear trends. This is interesting because it suggests least effect of late hydrothermal alterations and metamorphism. MgO-Sr plot does not show any significant trend. For further evaluation of crystallization behaviour few HFSEs, which are supposed to be immobile during the post-magmatic processes (Pearce and Cann 1973; Winchester and Floyd 1976; Floyd and Winchester 1978; Rollinson 1993; Jochum and Verma 1996), are also plotted against $\mathrm{MgO}$ contents (figure 6). Some interesting results are noted on these plots. In most of the plots two distinct crystallization trends are noticed; one group of samples show higher concentrations of HFSEs than the other group of samples. The samples with higher HFSE concentrations belong to calc-alkaline type (Sample nos. CGT06/32, 33 and 40). The other group contains tholeiitic and calc-alkaline both. Other important observation is that both groups have overlapping $\mathrm{MgO}$ contents (4-10 wt\%) with different HFSE contents, i.e., one group has considerably higher concentration of HFSEs than the other group with similar $\mathrm{MgO}$ contents. This feature strongly suggests that both groups cannot be derived from a single batch of magma; definitely derived from different magma batches. This also explains the trends observed for $\mathrm{TiO}_{2}$ and $\mathrm{P}_{2} \mathrm{O}_{5}$ (figure 4). To avoid confusion, in subsequent paragraphs, calc-alkaline group with higher concentration of HFSEs will be recognized as CMD-1 and other as CMD-2 (CMD: Chhotanagpur metabasite dyke). The discrimination between CMD-1 and CMD-2 is also clearly
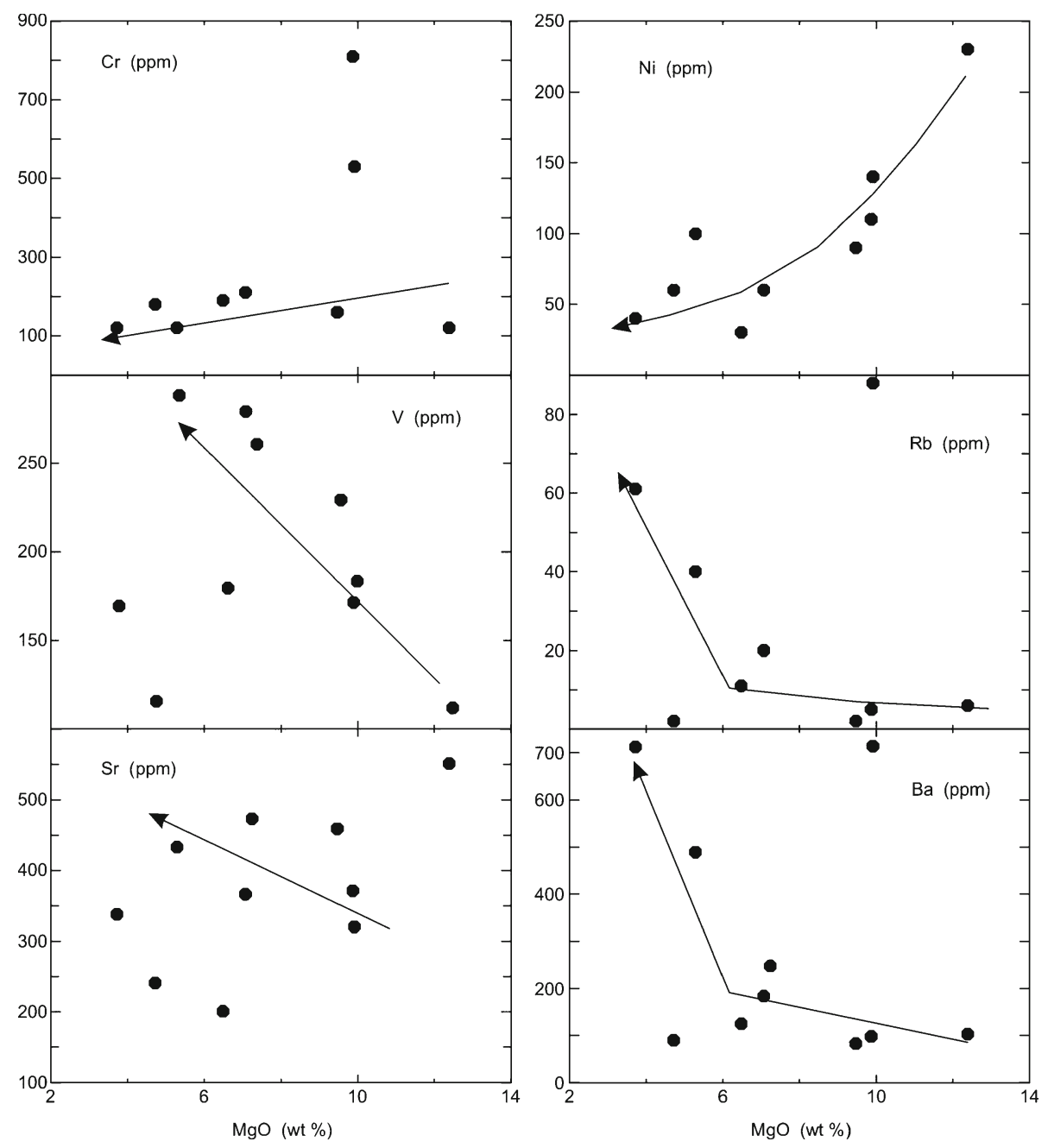

Figure 5. Harker-type variation diagram for $\mathrm{Cr}$, Ni and few LILEs. 

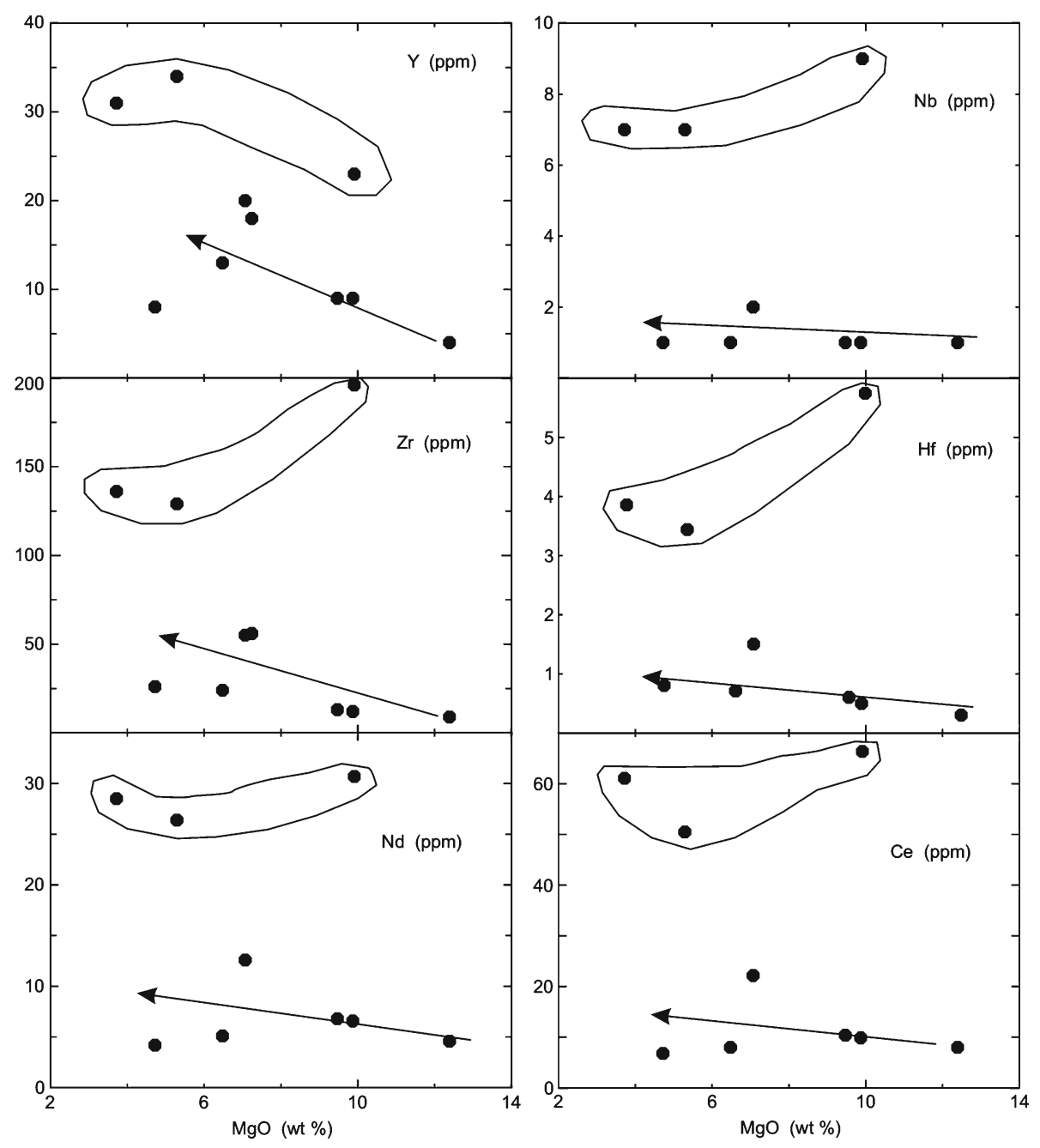

Figure 6. Harker-type variation diagram for HFSEs.

visible in $\mathrm{Zr} / \mathrm{Nb}$ and $\mathrm{Zr} / \mathrm{Nd}$ ratios plot (figure 7 ); the CMD-1 has distinctly different $\mathrm{Zr} / \mathrm{Nb}$ and $\mathrm{Zr} / \mathrm{Nd}$ ratios than the CMD-2. These ratios are relatively high $(\mathrm{Zr} / \mathrm{Nb}$ ratio between 19.4 and 27.5 and $\mathrm{Zr} / \mathrm{Nd}$ ratio between 4.4 and 6.4) in the CMD2 than in CMD-1; which has $\mathrm{Zr} / \mathrm{Nb}$ ratios between 9 and 13 and $\mathrm{Zr} / \mathrm{Nd}$ ratio is $<2$.

Figure 8 presents primordial mantle normalized multi-element (ME) spidergrams and chondrite normalized rare-earth element (REE) patterns for the studied samples. These patterns clearly corroborate two different groups observed in previous plots. Very distinct ME and REE patterns are observed for CMD-1 and CMD-2; CMD-1 has higher concentrations of all the elements than the CMD-2. Most distinguishable feature noted in these two groups on ME patterns (figure 8a) is that the CMD-2 shows prominent positive anomalies in $\mathrm{Ba}$ and $\mathrm{Sr}$ whereas $\mathrm{Rb}, \mathrm{Th}, \mathrm{Nb}-\mathrm{Ta}$ and $\mathrm{Hf}-$ $\mathrm{Zr}$ show negative anomalies. On the other hand, CMD-1 shows entirely different patterns; no prominent anomalies noted in $\mathrm{Rb}, \mathrm{Ba}$, Th, and $\mathrm{Hf}-\mathrm{Zr}$. Small negative anomalies are observed for $\mathrm{Sr}$ and

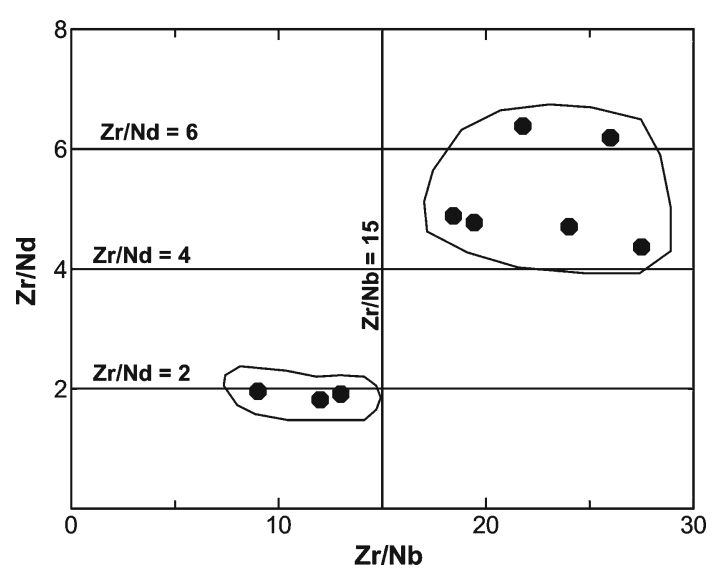

Figure $7 . \mathrm{Zr} / \mathrm{Nb}$ vs. $\mathrm{Zr} / \mathrm{Nd}$ ratio plot.

$\mathrm{Ti}$ in the first group. Other important point is that both groups show consistent variation. Overall, all elements show enriched ME patterns except $\mathrm{Hf}, \mathrm{Zr}$ and $\mathrm{Y}$ contents in few samples (particularly sample no. CGT06/53) of the CMD-2 show 

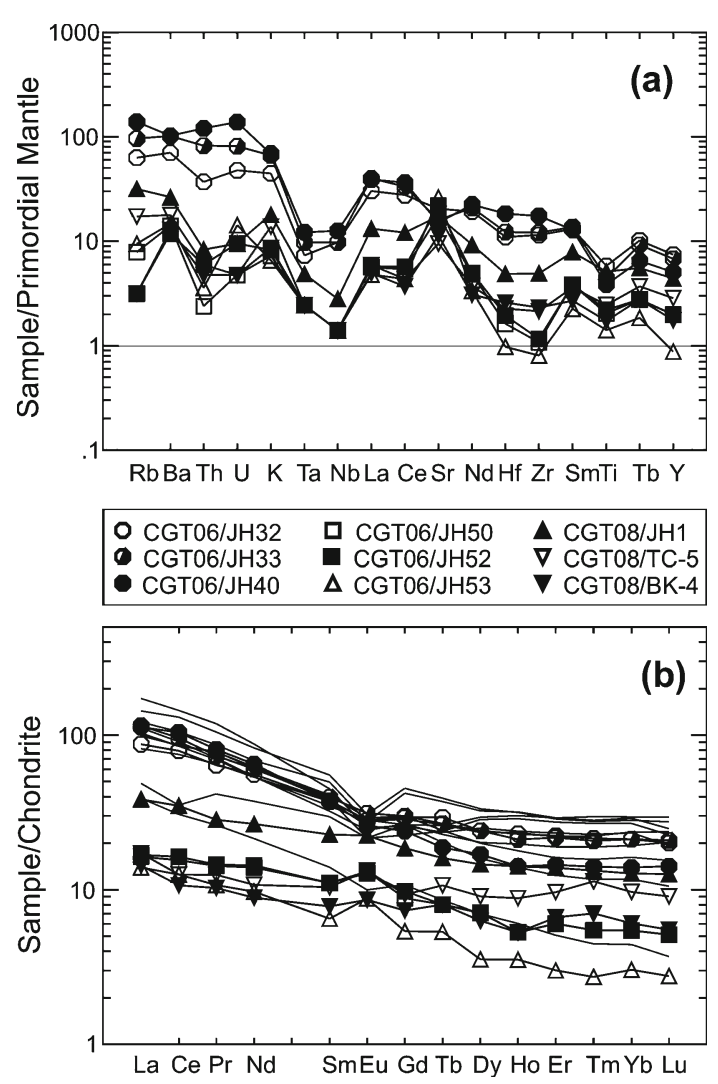

Figure 8. Primordial mantle normalized multi-element spidergrams and chondrite normalized rare-earth element patterns for metabasite dykes from the Chhotanagpur Gneissic Terrain. Primordial mantle and chondrite values are taken from McDonough et al (1992) and Evensen et al (1978). REE data of metabasite dyke samples studied by Kumar and Ahmad (2007) are also plotted (gray lines) for comparison.

very close similarities with primordial mantle values. The REE patterns (figure 8b) observed in these rocks are also distinct. The CMD-1 has relatively higher concentrations of REE than the CMD-2. The CMD-1 has slightly enriched light REE (LREE) with flat heavier REE (HREE) patterns and no Eu anomaly noticed but most of the CMD-2 samples show flat REE patterns with most samples show positive $\mathrm{Eu}$ anomaly. Positive $\mathrm{Eu}$ anomaly is probably due to plagioclase accumulation. Another important observation is that HREE patterns of the CMD-2 samples show wide range; from slightly enriched to slightly depleted patterns. Variation in HREE patterns suggest their derivation from different magma batches generated at different depths. For example, depletion in HREE relative to LREE indicates presence of garnet in the source. But, in any case, these ME and REE patterns clearly corroborate that metabasite dykes of the CGT are fed by at least two distinct magmas, i.e., calc-alkaline and tholeiite.

ME and REE patterns for the studied metabasite dykes are also compared with other studied metabasite dykes of this region (Kumar and

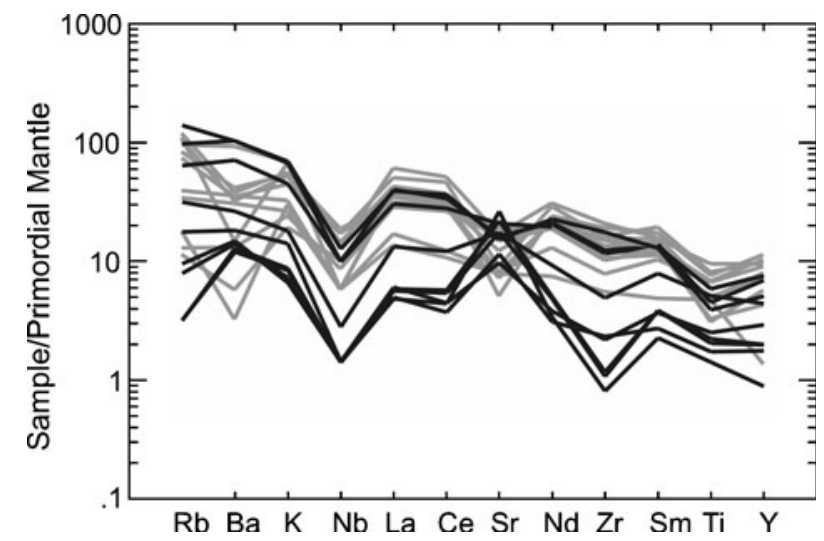

Figure 9. Primordial mantle normalized ME patterns for metabasite dykes of present study (black lines) from the Chhotanagpur Gneissic Terrain are compared with ME patterns for metabasite dyke samples (gray lines) studied by Kumar and Ahmad (2007). Primordial mantle values are taken from McDonough et al (1992).

Ahmad 2007) (figures 8b and 9). REE patterns of majority metabasite samples, studied by Kumar and Ahmad (2007), show very close similarities with calc-alkaline types of present studied samples except negative Eu anomalies shown by previously studied samples. ME patterns also look similar but very distinct differences noticed in $\mathrm{Ba}$ and Sr contents; they behave very differently. Other element compositions are very similar. However, in general, samples studied by Kumar and Ahmad (2007) show close similarities with present studied samples.

\section{Discussion}

\subsection{Crustal contamination}

It is suggested that, in comparison to volcanic rocks, degree of crustal contamination in dykes is less, and sometimes even absent (Tarney and Weaver 1987). However, it is worth to discuss about the possibility of crustal contamination in the studied samples before discussing further on their geochemical characteristics. From the geochemical diagrams presented above it is inferred that there is a least possibility of alteration due to postmagmatic processes in the studied metabasite samples. This is evident from the LILE concentrations in these samples which show very consistent variations (figures 5 and 8a); generally altered samples show very inconsistent LILE behaviour. It is well-known that mafic samples with crustal contamination through subduction related processes may show negative $\mathrm{Nb}-\mathrm{Ta}$ and $\mathrm{Hf}-\mathrm{Zr}$ anomalies, positive Sr anomaly and enriched LREE patterns (Crawford 1989; Tatsumi and Eggins 1995; Zhao 
and Zhou 2007; Cai et al 2010). The geochemical characteristics of the studied samples elucidate presence of negative $\mathrm{Nb}-\mathrm{Ta}$ and $\mathrm{Hf}-\mathrm{Zr}$ anomalies and positive Sr anomaly in the second group samples, which indicate possibility of crustal contamination. On the other hand, the second group having negative $\mathrm{Nb}-\mathrm{Ta}$ but with small negative $\mathrm{Sr}$ anomaly and $\mathrm{Hf}-\mathrm{Zr}$ anomaly either suggest no or, if present, very nominal crustal contamination. But, interestingly, REE patterns do not support these inferences; the first group has little enriched LREE patterns but the second group do not. Therefore, it is difficult to assess crustal contamination in these samples on the basis of available geochemical data; we require radiogenic isotope data to reach some specific conclusion. It is important to mention that the LILE such as Sr, K (alkalis), Rb, $\mathrm{Ba}, \mathrm{Sr}$, etc., are thought to be mobile during the post-magmatic secondary processes like hydrothermal alteration and metamorphism (Pearce and Cann 1973; Seewald and Seyfried 1990; Verma 1992; Condie and Sinha 1996), whereas high-field strength elements (HFSE) such as Ti, Zr, Y, $\mathrm{Nb}, \mathrm{P}, \mathrm{REE}$, etc., are thought to be relatively immobile under hydrothermal alteration and midamphibolite facies metamorphic conditions (Pearce and Cann 1973; Winchester and Floyd 1976; Floyd and Winchester 1978; Rollinson 1993; Jochum and Verma 1996).

For further evaluation of crustal contamination, $\mathrm{Zr} / \mathrm{Y}$ and $\mathrm{Nb} / \mathrm{Y}$ ratios of studied metabasite samples along with average crust and primordial mantle are plotted (figure 10). Most samples plot between primordial mantle (PM) and average crust (AC). Although few samples plot very close to PM, others follow a trend which suggests a possibility of crustal contamination. This indicates that

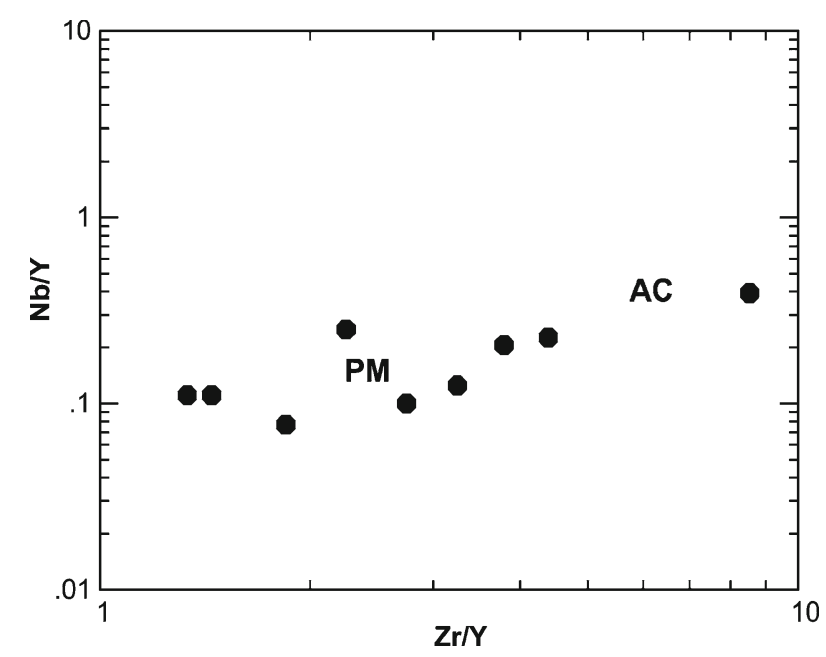

Figure 10. $\mathrm{Nb} / \mathrm{Y}$ vs. $\mathrm{Zr} / \mathrm{Y}$ ratio plot for metabasite samples of present study compared with primordial mantle (PM; after McDonough and Sun 1995), and average continental crust (AC; after Rudnick and Fountain 1995). these dykes are derived from a modified mantle source. This modification might be due to mantle metasomatism through subduction related processes. It is already explained in the geochemistry sections that one group of samples (CMD-1) clearly show calc-alkaline nature, whereas few samples of other group (CMD-2) show calc-alkaline affinity. Calc-alkaline rocks ranging from basalt to rhyolite are normally related to island-arc or subductionzone magmatism (Rickwood 1989; Wilson 1989; Hooper 1994). Previous researchers also suggested that Mesoproterozoic metabasite intrusive rocks are produced by melts generated from an enriched mantle source modified by crustal contamination (Ghose et al 2005; Kumar and Ahmad 2007; Ghose and Chatterjee 2008).

Ghose et al (2005), who studied metabasite samples from south of the Damodar graben, recognized two types, low-Ti and high-Ti. They suggest that petrogenesis of low-Ti type is emplaced in an intracratonic setting and related to plumegenerated magmatism. On the other hand, highTi type may be fed from a melt generated from mantle modified through subducted oceanic crust. Kumar and Ahmad (2007) suggest that metabasite (amphibolites) dykes of the CGT are fed by variable degree of partial melting of enriched mantle sources and subsequent fractionation of clinopyroxene, olivine, plagioclase and $\mathrm{Fe}-\mathrm{Ti}$ oxides. They further mention that crustal contamination had modified the source; however, it is not mentioned how it was modified. We believe that it is probably due to some subduction related processes which metasomatized the source region. However, these authors (Kumar and Ahmad 2007) favoured emplacement of these dykes in a continental rift/lithospheric extension tectonic environment rather than subduction setting.

\subsection{Tectonic environment of emplacement}

The geochemical data examined for the metabasite dyke samples from the CGT during the present study and also samples studied by Kumar and Ahmad (2007) show some important characteristics.

- They show basaltic-basaltic andesite to andesite geochemical characteristics and classified as tholeiite (low-K) to calc-alkaline (mostly mediumK) type basalts on classificatory plots (figure 3 ).

- Most of the variation diagrams demonstrate logically fair differentiation trends (figures 4 to 6 ).

- HFSEs variation plots (figure 6) suggest at least two magma batches fed the metabasite dykes; recognized as CMD-1 and CMD-2.

- All the CMD-1 samples show calc-alkaline nature (figure 3) and have high HFSE contents than the 
CMD-2 with overlapping $\mathrm{MgO}$ contents (figures 6 and 8). This definitely suggests different genetic history for both the types.

- Most of the samples studied by Kumar and Ahmad (2007) show very similar ME and REE patterns as observed for the CMD-1 (figures $8 \mathrm{~b}$ and 9$)$.

- Few samples of CMD-2 also show calc-alkaline nature. This advocates that this group has samples of tholeiitic and calc-alkaline nature with one sample of picritic nature (table 1a).

- Most samples of the CMD-2 have high Mg\# (mostly between 60 and 72), suggesting their derivation from primary melts.

- The CMD-1 samples show smooth REE and ME patterns (figure 8) suggesting their genetic relationship with each other and derived from the same melt.

- On the other hand, the CMD-2 samples have some different trends; one sample (CGT08/JH1) show intermediate pattern (probably differentiated sample of tholeiitic group) and others show variations in HFSE (including REE) patterns (figure 8). This probably suggests their derivation from different magma batches.

- Trace element patterns observed for Nb-Ta, Hf$\mathrm{Zr}$, Sr and Y suggest involvement of subduction related processes.

- Very limited variation is observed for LILEs in both groups advocating least effect of postmagmatic processes like hydrothermal alteration and metamorphism. These geochemical characteristics indicate that source region (responsible for the generation of CGT metabasalts) was modified through processes involved in destructive plate setting. Although it is difficult to predict any definite pattern in the generation of different types of melts in destructive plate margins, it is observed that magmas change in composition from tholeiite to calc-alkaline to alkaline from trench (Wilson 1989). This also implies that magma generated at different depths in such a tectonic setting produces tholeiite (shallower depth) to calc-alkaline to alkaline (relatively greater depth). Almost similar picture is observed for the present case as studied region has rocks of tholeiite to different calc-alkaline nature.

Sheth et al (2002) cautioned that term 'calcalkaline' should be used very carefully and it should be identified with right criteria. In this study, many geochemical parameters are used to classify the studied rocks and further examined on many variation plots and ME-REE patterns. All these geochemical explanations suggest that CMD-1 is calc-alkaline in nature and CMD-2 has tholeiitecalc-alkaline association. To corroborate these assumptions, few discrimination diagrams which provide explicit affirmation to distinguish a former tectonic environment (figure 11) are used. Discrimination diagram based on $\mathrm{Zr}$ and $\mathrm{Ti}$ (figure 11a; Pearce 1982) effectively separate volcanic arc basalts from the within-plate type; all samples from the present study show volcanic-arc nature whereas
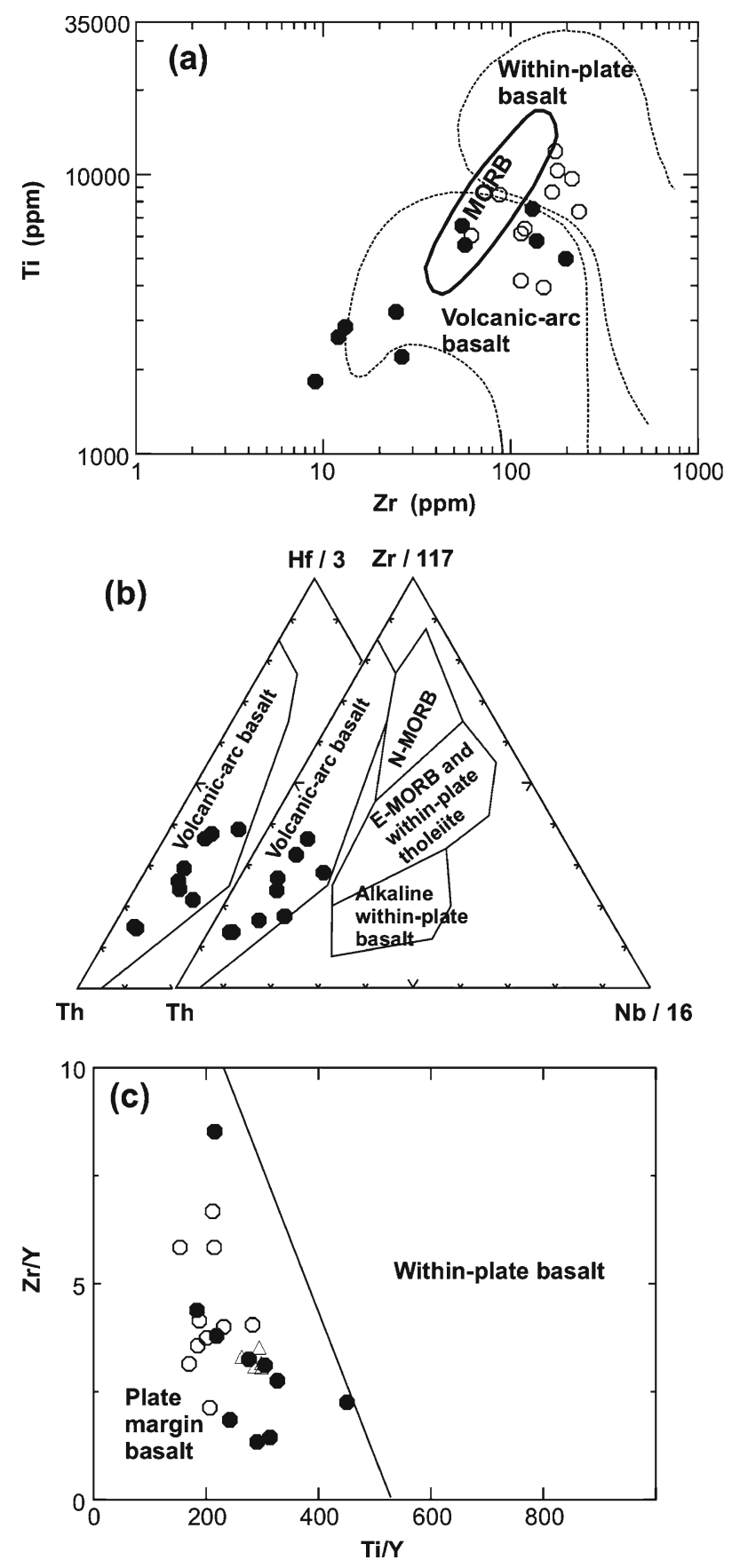

Figure 11. Discrimination diagrams for distinguishing tectonic environments. (a) $\mathrm{Zr}-\mathrm{Ti}$ variation plot (after Pearce 1982); (b) Th-Hf-Nb and Th-Zr-Nb variation plots (after Wood 1980); (c) Ti/Y-Zr/Y variation plot (after Pearce and Gale 1977). 0 : present studied mertabasite samples; $\bigcirc$ : metabasite samples studied by Kumar and Ahmad (2007); $\triangle$ : metabasite samples studied by Ghose et al (2005). 
earlier studied samples (Kumar and Ahmad 2007) plot in both fields. Volcanic-arc nature is also corroborated on $\mathrm{Th}-\mathrm{Hf}-\mathrm{Nb}$ (and also $\mathrm{Th}-\mathrm{Zr}-\mathrm{Nb}$ ) diagram (figure 11b; Wood 1980). Another discrimination diagram, based on $\mathrm{Ti} / \mathrm{Y}$ and $\mathrm{Zr} / \mathrm{Y}$ ratios (figure 11c; Pearce and Gale 1977), all samples, including earlier studied samples (Ghose et al 2005; Kumar and Ahmad 2007), plot in plate-margin basalt field.

It is difficult to distinguish between basic rocks of oceanic island arc and active continental margins with the help of available geochemical data. Both have very little differences in their chemical compositions. In any case, geochemical data presented here clearly suggest that magma generated in destructive plate setting fed the mafic dykes of the CGT. Basic rocks emplaced at continental margins certainly have higher concentration of K, Sr, Ba, HFSEs, etc., than oceanic arc (Wilson 1989). CMD-1 calc-alkaline samples show higher concentrations of these elements which suggest their emplacement in a continental margin setting. But, certainly radiogenic isotope data is required for better understanding on the tectonic setting.

\section{Conclusions}

- A number of Mesoproterozoic ENE-WSW to E-W trending metabasite dykes are emplaced within the CGT. Their petrographic characteristics suggest that they are metamorphosed under amphibolites $\mathrm{P}-\mathrm{T}$ conditions.

- Geochemically they show low-K tholeiite and high-K calc-alkaline nature. High-field strength trace element (including rare-earths) compositions point out at least two petrogenetic histories for the generations of dykes in the CGT; recognized as CMD-1 and CMD-2. This is evident from high HFSE contents in the CMD-1 samples (calc-alkaline type) than the CMD-2 with overlapping $\mathrm{MgO}$ contents.

- The CMD-2 samples show variation from tholeiite to calc-alkaline with one sample of picritic nature.

- High $\mathrm{Mg} \#$ is observed in many samples of both groups suggesting their derivation from primary melt. Very limited variation is observed for LILEs in both groups suggesting least effect of postmagmatic processes like hydrothermal alteration and metamorphism. But, on the other hand, $\mathrm{Nb}-$ $\mathrm{Ta}, \mathrm{Hf}-\mathrm{Zr}$, Sr and Y contents suggest involvement of subduction related processes. This observation implies that source region responsible for the generation of CGT metabasalts was modified through processes involved in destructive plate setting.
- Geochemical characteristics of the CMD-1 samples clearly indicate their co-genetic nature but the CMD-2 samples have some different geochemical patterns, which probably suggest their derivation from different magma batches.

- Magmas generated in any destructive plate tectonic setting change their composition from tholeiite to calc-alkaline to alkaline from trench, which may also be correlated to depth from where melts generated. In general, tholeiitic melt is generated at shallower depth in comparison to calc-alkaline to alkaline which produced at relatively greater depths. Comparable picture is observed for the present case. Geochemistry observed for present studied samples suggests emplacement of metabasite dykes in a continental margin setting.

\section{Acknowledgements}

The authors would like to thank the Department of Science and Technology, New Delhi for providing research grant for the present work (ESS/16/ 299/2006). They are thankful to N V Chalapathi Rao and N C Ghose for their constructive comments/suggestions during the preparation of the paper. Authors are also grateful to journal reviewers (Dalim Paul and D Asthana) for their useful and constructive comments which helped to improve the paper considerably.

\section{References}

Acharyya S K 2003 The nature of Mesoproterozoic central Indian Tectonic zone with exhumed and reworked older granulites; Gondwana Res. 6 197-214.

Baksi A K 1995 Petrogenesis and timing of volcanism in the Rajmahal flood basalt province, northeastern India; Chem. Geol. 121 73-90.

Bhattacharya D K, Mukherjee D and Barla V C 2010 Komatiite within Chhotanagpur Gneissic Complex at Semra, Palamau district, Jharkhand: Petrological and geochemical fingerprints; J. Geol. Soc. India 76 589-606.

Bleeker W and Ernst R E 2006 Short-lived mantle generated magmatic events and their dyke swarms: The key unlocking Earth's paleogeographic record back to $2.6 \mathrm{Ga}$; In: Dyke Swarms - Time Markers of Crustal Evolution (eds) Hanski E, Mertanen S, Rämö T and Vuollo J (London: Taylor \& Francis), pp. 3-26.

Cai K, Sun M, Yuan C, Zhao G, Xiao W, Long X and Wu F 2010 Geochronological and geochemical study of mafic dykes from the northwest Chinese Altai: Implications for petrogenesis and tectonic evolution; Gondwana Res. 18 $638-652$.

Chatterjee N and Ghose N C 2011 Extensive Early Neoproterozoic high-grade metamorphism in North Chotanagpur Gneissic Complex of the Central Indian Tectonic Zone; Gondwana Res., doi: 10.1016/j.gr.2010.12.003.

Chatterjee N, Crowley J L and Ghose N C 2008 Geochronology of the $1.55 \mathrm{Ga}$ Bengal anorthosite and Grenvillian 
metamorphism in the Chotanagpur gneissic complex, eastern India; Precamb. Res. 161 303-316.

Condie K C and Sinha A K 1996 Rare earth and other trace element mobility during mylonitization: A comparison of the Brevard and Hope Valley shear zones in the Appalachian Mountains, USA; J. Metmorph. Geol. 14 213-226.

Crawford A J 1989 Boninites and Related Rocks (London: Unwin Hyman), 465p.

Devaraju T C 1995 Dyke swarms of peninsular India; Geol. Soc. India Memoir 33 451p.

Ernst R E, Srivastava R K, Bleeker W and Hamilton M 2010 Precambrian Large Igneous Provinces (LIPs) and their dyke swarms: New insights from high-precision geochronology integrated with paleomagnetism and geochemistry; Precamb. Res. 183 vi-xi.

Evensen N M, Hamilton P J and O'Nion R K 1978 Rare earth abundances in chondritic meteorites; Geochim. Cosmochim. Acta 42 1199-1212.

Floyd P A and Winchester J A 1978 Identification and discrimination of altered and metamorphosed volcanic rocks using immobile elements; Chem. Geol. 21 291-306.

Ghose N C 1983 Geology, tectonics and evolution of the Chhotanagpur granite gneiss complex, Eastern India; In: Structure and Tectonics of Precambrian Rocks of India (ed.) Sinha-Roy S, Recent Researches in Geology (Delhi: Hindustan Publishing Corporation), 10 211-247.

Ghose N C and Mukherjee D 2000 Chhotanagpur gneissgranulite complex, Eastern India - A kaleidoscope of global events; In: Geology and Mineral Resources of Bihar and Jharkhand (eds) Trivedi A N, Sarkar B C, Ghose $\mathrm{N} \mathrm{C}$ and Dhar $\mathrm{Y} \mathrm{R}$, Institute of Geoexploration and Environment: Patna, Monograph 2 33-58.

Ghose N C and Chatterjee N 2008 Petrology, tectonic setting and source of dykes and related magmatic bodies in Chotanagpur gneissic complex, eastern India; In: Indian Dyke: Geochemistry, Geophysics and Geochronology (eds) Srivastava R K, Sivaji C and Chalapathi Rao N V (New Delhi: Narosa Publishing House Pvt Ltd), pp. 471-493.

Ghose N C, Mukherjee D and Chatterjee N 2005 Plume generated Mesoproterozoic mafic-ultramafic magmatism in the Chotanagpur mobile belt of eastern Indian shield margin; J. Geol. Soc. India 66 725-740.

Halls H C 1982 The importance and potential of mafic dyke swarms in studies of geodynamic process; Geosci. Canada 9 145-154.

Halls H C 2008 The importance of integrating paleomagnetic studies of Proterozoic dykes with U-Pb geochronology and geochemistry; In: Indian Dyke: Geochemistry, Geophysics and Geochronology (eds) Srivastava R K, Sivaji C and Chalapathi Rao N V (New Delhi: Narosa Publishing House Pvt Ltd), pp. 19-40.

Hooper P R 1994 Sources of continental flood basalts: The lithospheric component; In: Volcanism (ed.) Subbarao K V (New Delhi: Wiley Eastern Limited), pp. 29-53.

Hou G T, Santosh M, Qian X L, Lister G and Li J H 2008 Configuration of the Late Paleoproterozoic supercontinent Columbia: Insights from radiating mafic dyke swarms; Gondwana Res. 14 395-409.

Irvine T N and Baragar W R A 1971 A guide to chemical classification of the common volcanic rocks; Canadian J. Earth Sci. 8 523-548.

Jensen L S 1976 A new cation plot for classifying sub-alkaline volcanic rocks; Ontario Division Mines Misc. Paper 6621.

Jochum K P and Verma S P 1996 Extreme enrichment of $\mathrm{Sb}, \mathrm{Tl}$, and other trace elements in altered MORB; Chem. Geol. 130 289-299.

Kent $\mathrm{R}$ W, Pringle M S, Muller R D, Saunders A D and Ghose N C $2002{ }^{40} \mathrm{Ar} /{ }^{39} \mathrm{Ar}$ geochronology of the
Rajmahal basalts, India and their relationship to the Kerguelen Plateau; J. Petrol. 43 1141-1153.

Kumar A and Ahmad T 2007 Geochemistry of the mafic dykes in parts of Chotanagpur gneissic complex: Petrogenetic and tectonic implications; Geochem. J. 41 $173-186$.

Le Maitre R W 2002 Igneous Rocks: A classification and glossary of terms, 2nd edition (Cambridge: Cambridge University Press) 236p.

Mahadevan T M 2002 Geology of Bihar and Jharkhand (Bangalore: Geological Society of India), 569p.

Mahadevan T M 2009 Precambrian geological and structural features of the Indian shield; J. Geol. Soc. India 72 35-55.

Mallik A K, Gupta S N and Ray Barman T 1991 Dating of early Precambrian granite-greenstone complex of the eastern Indian Precambrian shield with special reference to the Chotanagpur granite gneiss complex; Rec. Geol. Surv. India 125(2) 20-21.

McDonough W F and Sun S-S 1995 The composition of the Earth; Chem. Geol. 120 223-253.

McDonough W F, Sun S-S, Ringwood A E, Jagoutz E and Hofmann A W $1992 \mathrm{~K}, \mathrm{Rb}$ and Cs in the earth and moon and the evolution of the earth's mantle; Geochim. Cosmochim. Acta 56 1001-1012.

Meert J G 2002 Paleomagnetic evidence for a PaleoMesoproterozoic supercontinent Columbia; Gondwana Res. 5 207-215.

Mukhopadhyay D 1988 Precambrian of the eastern Indian shield; Geol. Soc. India Memoir 8 237p.

Murthy N G K 1987 Mafic dyke swarms of the Indian shield; In: Mafic Dyke Swarms (eds) Halls H C and Fahriig W F, Geol. Assoc. Canada Spec. Paper 34 393-400.

Naqvi S M and Rogers J J W 1987 Precambrian Geology of India (New York: Oxford University Press), 223p.

Pandey B K, Gupta J N and Lall Y 1986 Whole rock and $\mathrm{Rb}-\mathrm{Sr}$ isochron ages for the granites from Bihar mica belt of Hazaribagh, Bihar, India; Indian J. Earth Sci. 12 157-162.

Pearce J A 1982 Trace element characteristics of lavas from destructive plate boundaries; In: Andesites (ed.) Thorpe R S (Chichester: Wiley), pp. 525-548.

Pearce J A and Cann J R 1973 Tectonic setting of basic volcanic rocks investigated using trace element analysis; Earth Planet. Sci. Lett. 19 290-300.

Pearce J A and Gale G H 1977 Identification of oredeposition environment from trace element geochemistry of associated igneous host rocks; Geol. Soc. Spec. Publ. 7 $14-24$.

Pisarevsky S A, Wingate M T D, Powell C Mc A, Johnson S and Evans D A D 2003 Models of Rodinia assembly and fragmentation; In: Proterozoic East Gondwana: Supercontinent Assembly and Breakup (eds) Yoshida M, Windley B F and Dasgupta S, Geol. Soc. London Spec. Publ. 206 $35-55$.

Ramakrishnan M and Vaidyanadhan R 2010 Geology of India (Geol. Soc. India: Bangalore), 994p.

Rickwood P C 1989 Boundary lines within petrologic diagrams which use oxides of major and minor elements; Lithos 22 247-263.

Rogers J J W 1996 A history of continents in the past three billion years; J. Geol. 104 91-107.

Rogers J J W and Santosh M 2002 Configuration of Columbia, a Mesoproterozoic supercontinent; Gondwana Res. 5 5-22.

Rogers J J W and Santosh M 2009 Tectonics and surface effects of the supercontinent Columbia; Gondwana Res. $15373-380$.

Rollinson H R 1993 Using geochemical data: Evaluation, presentation, interpretation (Longman: Essex), 352p. 
Rudnick R L and Fountain D M 1995 Nature and composition of the continental crust: A lower crustal perspective; Rev. Geophys. 33 267-309.

Sarkar S N 1968 Precambrian stratigraphy and geochronology of Peninsular India: A synopsis (Dhanbad: Dhanbad Publications), pp. 1-33.

Seewald J S and Seyfried W E 1990 The effect of temperature on metal mobility in sub-seafloor hydrothermal systems: Constraints from basalt alteration experiments; Earth Planet. Sci. Lett. 101 388-403.

Sharma R S 2009 Cratons and Fold Belts of India (BerlinHeidelburg: Springer-Verlag), 304p.

Sheth H, Torres-Alvarado I S and Verma S P 2002 What is the "calc-alkaline rock series"?; Intern. Geol. Rev. 44 686-701.

Srivastava R K 2011 Dyke Swarms: Keys for Geodynamic Interpretation (Heidelburg: Springer-Verlag), 605p.

Srivastava R K, Sivaji C and Chalapathi Rao N V 2008a Indian Dyke: Geochemistry, Geophysics and Geochronology (New Delhi: Narosa Publishing House Pvt Ltd), $626 \mathrm{p}$.

Srivastava R K, Sivaji C and Chalapathi Rao N V 2008b Indian dyke through space and time: Retrospect and prospect; In: Indian Dyke: Geochemistry, Geophysics and Geochronology (eds) Srivastava R K, Sivaji C and Chalapathi Rao N V (New Delhi: Narosa Publishing House Pvt Ltd), pp. 1-18.

Srivastava R K, Chalapathi Rao N V and Sinha A K 2009 Cretaceous alkaline intrusives with affinities to aillikites from the Jharia area: Magmatic expression of metasomatically veined and thinned lithospheric mantle beneath the Singhbhum Craton, Eastern India; Lithos 112 407-418.

Tarney J and Weaver B L 1987 Geochemistry and petrogenesis of early Proterozoic dyke swarms; In: Mafic Dyke Swarms (eds) Halls H C and Fahriig W F, Geol. Assoc. Canada Spec. Paper 34 81-94.
Tatsumi Y and Eggins S M 1995 Subduction Zone Magmatism (Oxford: Blackwell), 211p.

Verma S P 1992 Seawater alteration effects on REE, K, $\mathrm{Rb}, \mathrm{Cs}, \mathrm{Sr}, \mathrm{U}, \mathrm{Th}, \mathrm{Pb}$, and $\mathrm{Sr}-\mathrm{Nd}-\mathrm{Pb}$ isotope systematic of mid-ocean ridge basalts; Geochem. J. 26159 177.

Verma S P, Torres-Alvarado I S and Sitelo-Rodriguez Z T 2002 SINCLAS: Standard igneous norm and volcanic rock classification system; Computer Geosci. 28 711715.

Wilson M 1989 Igneous Petrogenesis (London: Unwin Hyman), 466p.

Winchester J A and Floyd P A 1976 Geochemical magma type discrimination: Application to altered and metamorphosed basic igneous rock; Earth Planet. Sci. Lett. 28 459-469.

Winchester J A and Floyd P A 1977 Geochemical discrimination of different magma series and their differentiation products using immobile elements; Chem. Geol. 20 325-343.

Wood D A 1980 The application of a Th-Hf-Ta diagram to problems of tectonomagmatic classification and to establishing the nature of crustal contamination of basaltic lavas of the British Tertiary volcanic province; Earth Planet. Sci. Lett. 50 11-30.

Yakubchuk A 2010 Restoring the supercontinent Columbia and tracing its fragments after its breakup: A new configuration and a Super-Horde hypothesis; J. Geodyn. 50 166-175.

Zhao J H and Zhou M F 2007 Geochemistry of Neoproterozoic mafic intrusions in the Panzhihua district (Sichuan Province, SW China): Implications for subduction-related metasomatism in the upper mantle; Precamb. Res. 152 27-47.

Zhao G, Sun M, Wilde S and Li S 2004 A PaleoMesoproterozoic supercontinent: Assembly, growth and breakup; Earth Sci. Rev. 67 91-123. 